\title{
Efektivitas Penggunaan Edmodo Berbasis Project Based Learning untuk Meningkatkan Kemandirian Belajar Mahasiswa
}

\author{
Dwi Yuniasih Saputri ${ }^{1}$ \\ ${ }^{1}$ Dosen Pendidikan Guru Sekolah Dasar, Universitas Sebelas Maret \\ Email : dwiyuniasihsaputri@staff.uns.ac.id
}

\begin{abstract}
This study aims to analyze the effectiveness of using edmodo based on project-based learning to improve learning independence for Applied Science courses at PGSD. This research is an experimental study with a quasi experimental control design. The subjects of this study were the fourth semester PGSD undergraduate students of UNS which consisted of 65 students. The instrument used was the learning independence observation sheet and the pretest and posttest questions. Data analysis used Paired Sample T-test and the increase was calculated using gain normalization. The results showed that the project-based learning-based edmodo media was effectively used to increase student learning independence in Applied Science courses with a sig $=0.000$ $<0.05$. The normalization results of the gain are 0.81 so that the project-based learning-based edmodo media is included in the high criteria in increasing student learning independence in Applied Science courses in PGSD Study Program.
\end{abstract}

Keywords : Edmodo, Project Based Learning, Independent Learning, Applied Science

Abstrak. Penelitian ini bertujuan untuk menganalisis keefektifan penggunaan edmodo berbasis project based learning untuk meningkatkan kemandirian belajar mata kuliah IPA Terapan di PGSD. Penelitian ini merupakan penelitian eksperimen dengan desain quasi experiment control. Subjek penelitian ini yaitu mahasiswa S1 PGSD UNS semester IV yang terdiri dari 65 mahasiswa. Instrumen yang digunakan yaitu lembar observasi kemandirian belajar dan soal pretest dan posttest. Analisis data menggunakan Paired Sample T-test dan kenaikan dihitung menggunakan normalisasi gain. Hasil penelitian menunjukkan bahwa media edmodo berbasis project based learning efektif digunakan untuk meningkatkan kemandirian belajar mahasiswa pada mata kuliah IPA Terapan dengan nilai sig $=0,000<0,05$. Hasil normalisasi gain 0,81 sehingga media edmodo berbasis project based learning termasuk dalam kriteria tinggi dalam meningkatkan kemandirian belajar mahasiswa pada mata kuliah IPA Terapan di Prodi PGSD.

Kata Kunci : Edmodo, Project Based Learning, Kemandirian Belajar, IPA Terapan.

\section{PENDAHULUAN}

Pandemi Covid-19 yang terjadi di berbagai belahan dunia berdampak pada setiap komponen kehidupan termasuk pendidikan. Proses pembelajaran terus berjalan tanpa mengurangi esensinya meski berhadapan dengan pandemi. Pendidik sebagai ujung tombak harus mampu beradaptasi dengan situasi yang terjadi. Proses pembelajaran selama pandemi berubah dari tatap muka menjadi pembelajaran jarak jauh. Peran pendidik sangat diperlukan saat proses transisi ini karena Pendidik berfungsi sebagai fasilitator dalam pembelajaran. Pembelajaran tidak bisa menggunakan cara konvensional, tetapi diperlukan pembelajaran yang konseptual. Hal yang paling berpengaruh dalam perubahan ini adalah media pembelajaran.

Media pembelajaran diartikan sebagai alat bantu berupa fisik dan non fisik yang digunakan oleh Pendidik dalam menyampaikan materi kepada siswa agar lebih efektif dan efisien. Sehingga materi 
pembelajaran lebih cepat diterima siswa secara utuh serta menarik siswa untuk belajar lebih banyak. (Musfiqon, 2012).

Media pembelajaran yang dimanfaatkan dengan tepat dalam proses pembelajaran akan menjadi alat pendukung yang lebih efektif dan efisien dalam mencapai tujuan pembelajaran. Selain itu media pembelajaran juga akan meningkatkan motivasi belajar siswa dan kemandirian belajar peserta didik hal ini sejalan dengan pernyataan yang dikemukakan Sanaky (2009) bahwa manfaat media pembelajaran antara lain: (a) Dengan menggunakan media pembelajaran maka proses pembelajaran akan lebih menarik sehingga dapat memotivasi pembelajaran siswa; (b) Dapat memperjelas materi pembelajaran sehingga siswa dapat dengan mudah memahami materi baik di kelas maupun secara mandiri; (c) dengan menggunakan media pembelajaran, proses pembelajaran menjadi lebih variatif. Materi tidak hanya disampaikan secara lisan, agar siswa tidak cepat bosan dan lebih efektif dan efisien; dan (d) Siswa menyimak materi yang disampaikan Pendidik, lebih banyak melakukan kegiatan pembelajaran seperti: mengamati, mengerjakan, mendemonstrasikan, dan lain-lain. Ciri-ciri media pembelajaran dapat mempromosikan pengalaman kelas sehingga menumbuhkan keterlibatan belajar siswa. Pada pembelajaran jarak jauh, Media pembelajaran harus disesuaikan dengan kebutuhan dan kondisi yang ada. Media pembelajaran dibuat secara berbeda untuk mengoptimalkan pembelajaran. Media pembelajaran yang baik mampu mengatasi masalah-masalah yang biasa terjadi pada saat pembelajaran jarak jauh. Hal ini menekankan bahwa media pembelajaran yang membuat bosan dan jenuh harus dihindari. Pada kenyatannya pada pembelajaran jarak jauh Pendidik menggunakan media pembelajaran yang monoton. Pendidik hanya memindahkan kelas konvensional ke kelas daring.

Berdasarkan hal tersebut, pendidik sebaiknya mampu memilih media pembelajaran yang efisien dan efektif. Saat ini, banyak tersedia aplikasi edukasi dengan platform media sosial. Salah satu platform edukasi tersebut, yaitu Edmodo. Edmodo didirikan pada tahun 2008 oleh Nicolas Brog dan Jeff O'Hara untuk tujuan pembelajaran. Edmodo adalah lingkungan sekolah berbasis jejaring sosial (school based environment) yang ditujukan untuk Pendidik, dan orang tua. Menurut Mokhtar (2018), Edmodo adalah situs platform pembelajaran sosial untuk pendidik, peserta didik, dan orang tua. Seperti halnya jejaring sosial lainnya, Edmodo dapat diakses gratis di situs www.edmodo.com. Edmodo bertujuan membantu pendidik memanfaatkan fasilitas jejaring sosial yang sesuai dengan kondisi pembelajaran di kelas. Edmodo dirancang untuk menciptakan interaksi antara pendidik dan menekankan pada komunikasi cepat, polling, tugas, berbagi ide, dan banyak lagi hal lainnya. Sebagai seorang pendidik, Edmodo menyediakan fitur untuk berbagi file, tautan, tugas, dan cara penilaian. Bagi para peserta didik, Edmodo menyediakan fitur untuk mampu berkomunikasi secara langsung dengan pendidik, berdiskusi dengan lain, menyerahkan tugas secara langsung dan masih banyak lagi.

Chandler dan Redman (2013: 59) memaparkan bahwa gaya pembelajaran Edmodo mampu meningkatkan pembelajaran secara kolaboratif dengan saling berbagi dan belajar satu sama lain dalam platform tersebut. Dengan berpenampilan layaknya sistem interaksi Facebook, Edmodo mengajari tentang tanggung jawab dan perilaku sehingga pada saatnya nanti mereka bisa menjadi pengguna jejaring sosial yang bertanggung jawab. Selain itu, secara tidak langsung mereka juga belajar mengemukakan pendapat secara terstruktur dan tertulis. Edmodo juga hadir dengan banyak permainan dan aplikasi yang membantu untuk belajar dengan interaktif dan menyenangkan.

Pendidik dapat menggunakan teknologi seperti Edmodo dalam mengajar menulis. Yancey (2009: 29) menyatakan bahwa jika sekolah ingin memenuhi tujuan mereka untuk melibatkan semua, mereka harus mengakui peluang belajar yang ditemukan di luar sekolah dan terhubung dengan kegiatan tersebut. Untuk mencapai itu, banyak yang harus dilakukan, tidak sedikit di antaranya adalah memberikan dukungan teknologi yang lebih baik untuk sekolah dan pengembangan professional.

Menggunakan Edmodo dalam mengajar menulis dapat memotivasi. Banyak pelajar hanya suka menggunakan komputer. Menurut Barrett dan Sharma (2007: 50), mereka menyukai latihan multimedia, karena mereka dapat melakukannya di tempat mereka sendiri. Mereka dapat membuat pilihan sendiri tentang bagaimana mengerjakan materi. Penggunaan teknologi dalam pengajaran bahasa Inggris sudah sangat umum saat ini. Menurut Smith dan Riling (2006: 2), penggunaan teknologi 
dalam pembelajaran bahasa membuat Pendidik dan dapat berkomunikasi melalui teks, suara dan video.

Berdasarkan hasil penelitian yang dilakukan oleh Rulviana (2018), media pembelajaran Edmodo membantu kelancaran proses belajar mengajar di PGSD Universitas Madiun. Hal tersebut juga sejalan dengan penelitian yang dilakukan oleh Aulia, Susilo, dan Subali (2019) bahwa penerapan pembelajaran menggunakan media Edmodo meningkatkan kemandirian belajar.

Salah satu metode yang dapat digunakan dalam pembelajaran adalah Project Based Learning (PBL) atau pembelajaran berbasis proyek. Project based learning (PBL) merupakan metode pembelajaran yang menempatkan siswa sebagai pusat dari proses pembelajaran. Ini banyak digunakan untuk menggantikan metode pengajaran tradisional di mana Pendidik, yang merupakan pusatnya, secara ketat mengikuti rencana pengajaran. Di kelas PBL, Pendidik mengarahkan siswa pada pembelajaran yang mereka inginkan atau pembelajaran yang mengikuti tujuan proyek. Proses PBL dengan demikian melibatkan proses pembelajaran yang mendalam dengan manajemen pembelajaran sistematis untuk mendapatkan hasil yang berguna dan dapat diterapkan, menciptakan motivasi, dan memperkuat keterampilan hidup yang diperlukan (Buck Institute for Education, 2010; Harris dan Katz, 2001; Moursund, 1999). Pembelajaran berbasis proyek tidak memiliki struktur tetap. Ini memiliki prosedur kerja yang rumit dan membutuhkan lebih banyak waktu untuk pengoperasian. Namun, ini fleksibel dan proses pembelajaran melibatkan interaksi dan kerjasama di antara peserta didik, antara peserta didik dan Pendidik, atau antara peserta didik dan spesialis. Lebih penting lagi, ketika Pendidik melaksanakan proyek dan proyek selesai, peserta didik akan merasa bangga dengan diri mereka sendiri. Hal ini membangkitkan motivasi bagi peserta didik untuk membuat proyek yang lebih baik di masa depan (Jung, Jun, dan Gruenwald, 2001).

Dalam pengelolaan kelas PBL, siswa dibagi menjadi beberapa kelompok dengan ukuran berbeda. Untuk kelompok kecil, semua siswa akan memiliki peran dan tanggung jawab yang sama dalam membuat proyek. Proyek ini memungkinkan peserta didik untuk memahami ideologi dan standar pembuatan proyek secara mendalam. Ini dapat memperkuat keterampilan dan perilaku kerja seumur hidup. Proyek ini juga memberikan kesempatan kepada pelajar untuk memecahkan masalah komunitas, survei karir masa depan, berkonsultasi dengan spesialis dan berkomunikasi dengan para intelektual menggunakan teknologi internet. Para peserta didik juga dapat mempresentasikan proyek mereka kepada kelompok sasaran di luar kelas. Proyek ini juga dapat memotivasi pelajar lain yang bermotivasi rendah, yang memandang belajar sebagai hal yang membosankan dan tidak berguna, untuk melihat signifikansi dan nilai pembelajaran (Buck Institute for Education, 2010).

Pembelajaran berbasis proyek saat ini dapat dirancang dengan menggunakan teknologi informasi, teknologi komputer, teknologi internet, dan multimedia (Chang, 2009). PBL melibatkan integrasi berbagai keterampilan untuk mencapai keterampilan yang lebih tinggi (Martinez, Herrero dan Pablo, 2010). Pembelajaran berbasis proyek di dalam edmodo mendorong kerja kelompok secara kooperatif melalui alat komunikasi yang telah Edmodo sediakan. Sikap kooperatif ketika di platform Edmodo memberikan pengalaman kehidupan nyata yang dapat ditemukan dalam kehidupan kerja nyata di masyarakat. Tujuan penelitian ini yaitu untuk menganalisis keefektifan penggunaan edmodo berbasis project based learning pada mata kuliah IPA Terapan di prodi PGSD Universitas Sebelas Maret. Penelitian ini diharapkan dapat memberikan wawasan penerapan pembelajaran pada masa pandemi Covid-19.

\section{METODE PENELITIAN}

Penelitian ini dilaksanakan di Universitas Sebelas Maret Surakarta. Objek penelitian ialah maha Pendidikan Pendidik Sekolah Dasar UNS semester IV. Jumlah maha 65, yang terdiri dari 32 maha kelas IV A dan 33 maha kelas B. Variable independent dalam penelitian ini adalah efektivitas penggunaan edmodo. Variable dependen adalah kemandirian belajar mata kuliah IPA. Teknik pengumpulan data menggunakan observasi dan tes. Instrumen yang digunakan dalam penelitian ini, yaitu lembar pengamatan kemandirian belajar sebelum dan sesudah pembelajaran menggunakan media berbasis 
Edmodo. Peningkatan kemandirian belajar dilihat dengan uji komparasi dua sampel berpasangan dan juga normalisasi gain untuk melihat peningkatan kemandirian belajar maha. Analisis data menggunakan Independent Simple T-test.

Penerimaan atau penolakan $\mathrm{HO}$ dengan menggunakan nilai signifikasi pada table Paried Samples Test kolom $\mathrm{t}$ (perhitungan dengan SPSS). Apabila nilai signifikasi $>5 \%$, maka $\mathrm{HO}$ diterima. Untuk melihat seberapa besar peningkatan yang terjadi, menggunakan rumus Normalized Gain (g) berikut.

$$
\langle g\rangle=\frac{\text { nilai postes }- \text { nilai pretes }}{\text { nilai maksimal }- \text { nilai pretes }} \times 100 \%
$$

Selanjutnya nilai Normalized Gain (g) yang diperoleh diterjemahkan sesuai dengan kriteria perolehan Normalized Gain (g) seperti yang disajikan dalam tabel I berikut:

Tabel 1. Kriteria perolehan Normalized Gain (g)

\begin{tabular}{cc}
\hline Normalized Gain & Kriteria \\
\hline$(\mathrm{g})<0,3$ & Rendah \\
\hline $0,3 \leq(\mathrm{g}) \leq 0,7$ & Sedang \\
\hline$(\mathrm{g})>0,7$ & Tinggi \\
\hline
\end{tabular}

\section{HASIL PENELITIAN DAN PEMBAHASAN}

Pembelajaran berbasis proyek pada platform Edmodo adalah metode pembelajaran yang menggunakan prinsip PBL dan media pembelajaran Edmodo untuk mendukung kegiatan pembuatan proyek di semua tahapan. Model PBL dengan media pembelajaran Edmodo terdiri dari 7 langkah termasuk 1) Orientasi, 2) Presentasi Topik Proyek, 3) Pengumpulan Informasi, 4) Perencanaan 5) Eksperimen, 6) Kesimpulan dan Laporan, 7) Evaluasi dan Promosi (Moursund, 1999; Jung, Jun dan Gruenwald, 2001; Lardizabal, 1970). Berikut uraian kegiatan pada setiap langkah PBL :

\section{Langkah 1 Orientasi}

Pendidik menemui peserta didik di kelas untuk menjelaskan dan menginformasikan peserta didik tentang tujuan pembelajaran, cakupan isi, kegiatan pembelajaran, metode pembelajaran berbasis Proyek di Edmodo. Pendidik juga menjelaskan pentingnya pencarian pengetahuan, perolehan pengetahuan, dan pembuatan proyek.

\section{Langkah 2 Presentasi Topik}

Pendidik menyajikan klip video atau gambar virtual dari peristiwa nyata yang berkaitan dengan mata kuliah IPA terapan, dalam hal ini pendidik menyuruh para peserta didik dalam membuat proyek berupa produk fermentasi dan pengawetan makanan minuman. Proyek yang dikembangkan berupa produk inovasi hasil fermentasi dan pengawetan makanan minuman seperti asap ikan, nugget sayur, yoghurt, asinan, manisan, dan susu tahu, dan lain-lain guna meningkatkan kemandirian belajar. Setelah itu, Anggota kelompok bertukar pikiran dan mendiskusikan topik proyek tersebut melalui Edmodo.

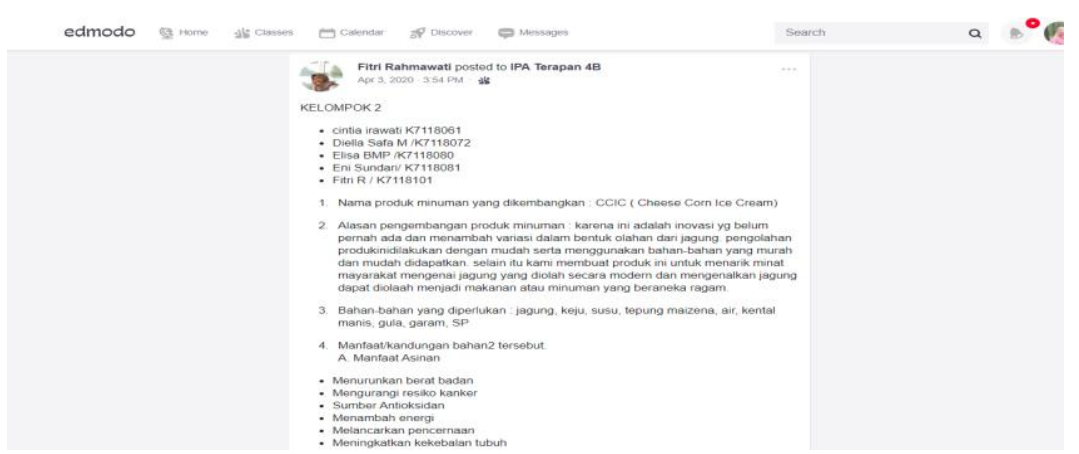

Gambar 1. Kelompok Mendiskusikan Topik Proyek 


\section{Langkah 3 Pengumpulan Informasi}

Setiap anggota mencari informasi terkait produk fermentasi dan pengawetan makanan minuman dari situs web, sumber belajar, dan sumber lain untuk mendukung proyek. Para anggota berbagi, berdiskusi, dan bertukar informasi ide yang mereka miliki serta membuat keputusan tentang informasi untuk mendukung proyek mereka di Edodo. Grup mengirimkan informasi yang dipilih dari setiap anggota kepada pendidik melalui Edmodo.

\section{Langkah 4 Perencanaan}

Semua anggota mengikuti program obrolan untuk bertukar pikiran, berbagi ide, dan merencanakan proyek mereka. Mereka harus mengatur prosedur, metode percobaan, metode pengumpulan data, penggunaan alat dan fasilitas, alat evaluasi, pengujian dan percobaan proyek, metode eksperimen, dan penggunaan sumber daya terkait. Kemudian kelompok menyerahkan informasi kelompok dan individu tentang ini kepada Pendidik melalui Edmodo.

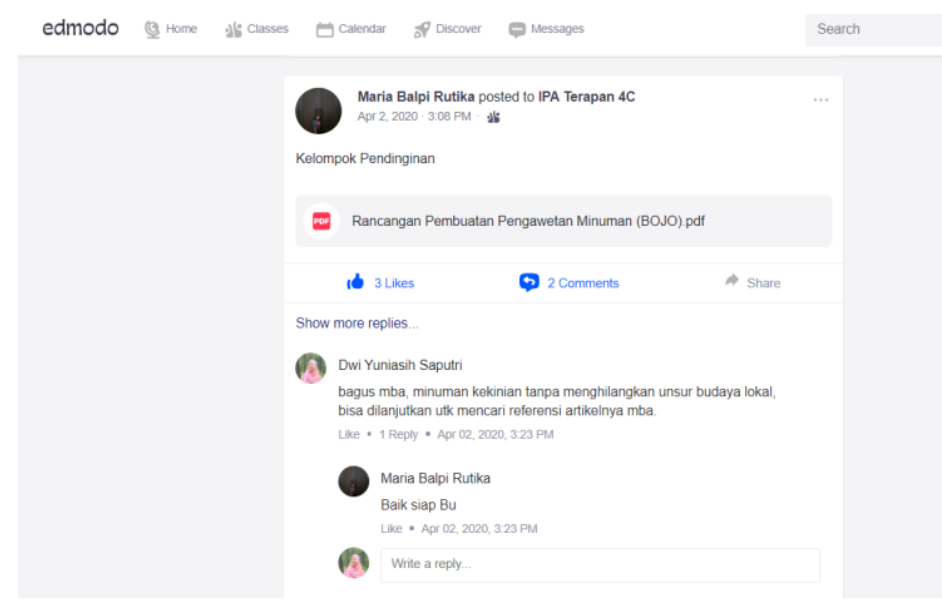

Gambar 2. Kelompok Mengunggah Rancangan Produk

\section{Langkah 5 Percobaan}

Semua anggota kelompok bekerja sama untuk melakukan percobaan proyek sesuai dengan rencana di laboratorium. Ini adalah praktik pembelajaran kooperatif anggota. Anggota kelompok mempelajari dan mendiskusikan rincian alat, fasilitas, dan prosedur proyek. Ketika mereka semua mengerti, mereka memulai eksperimen dan mengumpulkan data dari eksperimen tersebut bersamasama.

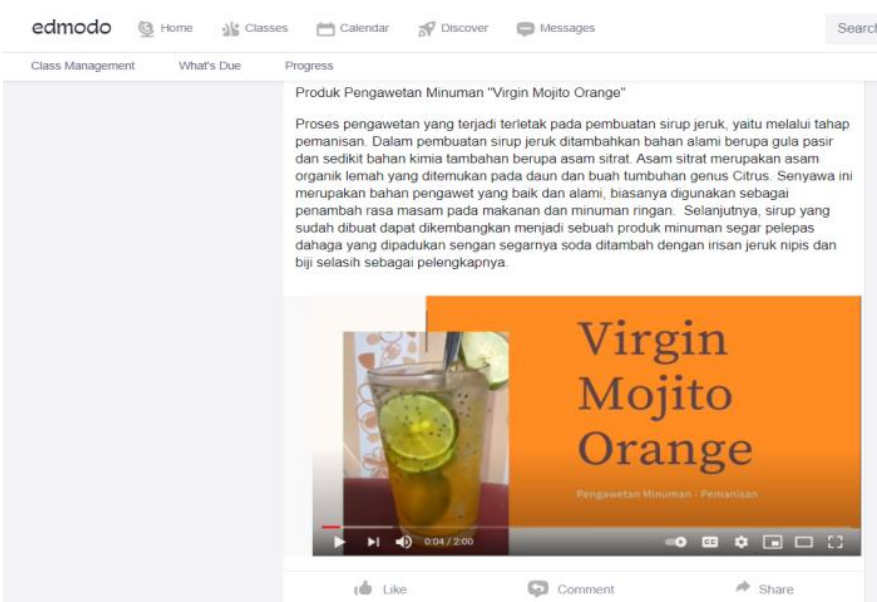

Gambar 3. Kelompok Mengunggah Bukti Percobaan Pembuatan Produk

\section{Langkah 6 Kesimpulan dan Laporan}

Ketika percobaan selesai, semua anggota mengumpulkan data dari percobaan dan mempresentasikannya di Web untuk mendiskusikan, menganalisis, dan menyimpulkan percobaan. 
Anggota kelompok kemudian saling membantu menulis laporan percobaan dan kelompok menyerahkan laporan dan kesimpulan kepada Pendidik melalui edmodo.

\section{Langkah 7 Evaluasi dan Promosi}

Kelompok mempresentasikan laporan dan kesimpulan di kelas edmodo. Pendidik dan anggota kelompok secara kooperatif mengevaluasi proyek mereka sendiri dan proyek kelompok lain. Anggota kelompok menggunakan hasil evaluasi untuk menyempurnakan dan meningkatkan proyek mereka untuk hasil tertinggi.

Berdasarkan penggunaan edmodo berbasis Project Based Learning kemandirian belajar mahasiswa nampak pada tanggungjawab dan keaktifan mahasiswa dalam membuat produk hasil olahan makanan baik dari fermentasi makanan, pengawetan makanan, dan pertanian sederhana. Hal tersebut sejalan dengan pendapat bahwa kemandirian belajar diartikan sebagai suatu proses pembelajaran dalam diri seseorang dalam mencapai tujuan tertentu yang dituntut aktif secara individu atau tidak bergantung kepada orang lain termasuk guru (Fajriyah, et. al, 2018, Rustyani, et. al, 2018).

Suhendri (2012) mengemukakan bahwa kemandirian merupakan sikap mental positif dari seorang individu untuk kenyamanan melakukan kegiatan perencanaan untuk mencapai tujuan dengan memposisikan atau mengkondisikan dirinya sehingga dapat mengevaluasi tentang diri sendiri dan lingkungannya. Kemandirian yang dimiliki oleh pembelajar yaitu untuk menumbuhkan rasa percaya diri yang sangat penting (Diniyah, 2018:15) serta lebih cepat dalam menerima materi pembelajaran sehingga membentuk karakter siswa menjadi lebih baik. Chia (2010) menyatakan bahwa pendidik memiliki kekuatan untuk mengontrol pembelajaran lingkungan yang dapat digunakan sebagai tempat latihan untuk mengarahkan kemandirian siswa. Dengan menggunakan edmodo berbasis Project Based Learning dapat menciptakan lingkungan untuk meningkatkan kemandirian belajar.

Penggunaan edmodo berbasis PBL efektif dalam penelitian ini dilihat berdasarkan adanya peningkatan kemandirian belajar pada mata kuliah IPA Terapan mahasiswa PGSD yang dianalisis dengan uji komparasi dua sampel berpasangan dan uji Normalized Gain.

Berdasarkan hasil output paired sample test didapat nilai sig $=0,000<0,05$ maka HO ditolak. Ini berarti bahwa kemandirian belajar maha PGSD pada mata kuliah IPA terapan setelah pembelajaran dengan media berbasis Edmodo tidak sama dengan sebelum pembelajaran dengan media berbasis Edmodo. Berikutnya akan dilihat berapa besar peningkatan kemandirian belajar berdasarkan nilai post-test dan nilai pre-test dengan uji Normalized Gain (g).

$$
(\mathrm{g})=(93-62) \times 100 \%=0.81
$$

$(100-62)$

Berdasarkan penghitungan dengan Normalized Gain $(\mathrm{g})$, diperoleh $(\mathrm{g})=0,81$. Berdasarkan tabel I, hasil tersebut menunjukkan bahwa peningkatan kemandirian belajar termasuk dalam kriteria tinggi. Hasil penelitian yang dicapai adalah pengembangan media pembelajaran edmodo berbasis project based learning yang valid, praktis, dan efektif ini sejalan dengan penelitian yang dilakukan oleh Dewi (2015), yang menyatakan bahwa kualitas pembelajaran menggunakan model PBL dengan pendekatan realistik berbantuan Edmodo termasuk kategori sangat baik. Pemanfaatan intemet dalam pembelajaran matematika berpotensi dalam menciptakan suasana belajar yang menyenangkan sehingga pembelajaran menjadi lebih bermakna. Jabar (2013) juga menyatakan bahwa pembelajaran elektronik mampu memadukan antara perkembangan teknologi dan informasi serta materi pembelajaran.

Kongchan menyatakan belajar dengan Edmodo efektif dalam matematika karena menggunakan pembelajaran memberikan pengalaman yang baik yaitu memudahkan maha dalam mengerjakan pertanyaan daring yang dapat dilakukan dari mana saja dan kapan saja (2012). Nee memaparkan bahwa pembelajaran dengan Edmodo juga dapat menumbuhkan sikap positif karena dapat menumbuhkan semangat dalam belajar dan meningkatkan interaksi antar maha (2014). 


\section{KESIMPULAN}

1. Ada perbedaan kemandirian belajar maha PGSD pada mata kuliah IPA Terapan antara sebelum dan sesudah menggunakan pembelajaran dengan Edmodo. Dari hasil uji t didapat sig (2-tailed) sebesar 0,000 yang nilainya kurang dari 0,05. Hal ini berarti HO tertolak dan disimpulkan bahwa ada perbedaan signifikan sikap kemandirian belajar sebelum dan sesudah menggunakan media pembelajaran Edmodo.

2. Pembelajaran menggunakan media pembelajaran Edmodo efektif dalam meningkatkan sikap kemandirian belajar maha PGSD UNS. Hasil perhitungan dengan $\mathrm{N}$-gain yaitu sebesar 0,81 yang artinya keefektifan dari penggunaan edmodo dalam peningkatan sikap kemandirian belajar pada maha PGSD pada mata kuliah IPA Terapan tergolong berkriteria tinggi.

\section{DAFTAR PUSTAKA}

Aulia LN, Susilo S, Subali B. Upaya peningkatan kemandirian belajar siswa dengan model problembased learning berbantuan media Edmodo. Jurnal Inovasi Pendidikan IPA. 2019 Apr 22;5(1):6978.

B Barrett \& Sharma, P. (2007). Blended Learning. The United Kingdom: Macmillan.

Buck Institute for Education, 2010. What is PBL? In (http://www.bie.org/about/what_is_pbl/) pada 20 April 2021.

Chandler, Paul D and Redman, Christine. Teaching teachers for the future: Modeling and Exploring Immersive Personal Learning Networks. Australian International Computing. Retrieved from www.usherbrooke.ca/.../AEC27-3_ChandlerRedman.I

Chang, C., 2009. Using Jigsaw Collaborative Learning Strategy in online discussion to foster a projectbased learning community on the web. Int J Instr Media. 36(2), pp. 221-33.

Chia, C. (2010). Autonomy in language learning: the use of it and internet resources. Singapore: McGraw- Hill Education.

Dewi, S. C. (2015). Implementasi Model PBL dengan Pendekatan Realistik Berbantuan Edmodo untuk Meningkatkan Literasi Matematika Kelas VII. Unnes Journal of Mathematics Education, 4 (2).

Diniyah, A. N., Akbar, G. A. M., Akbar, P., Nurjaman, A., \& Bernard, M. (2018). Analisis Kemampuan Kemampuan Penalaran dan Self Confidence Siswa SMA dalam Materi Peluang. Journal on Education, 1(1), 14-21.

Fajriyah, L., Nugraha, Y., Akbar, P., \& Bernard, M. (2018). PENGARUH KEMANDIRIAN BELAJAR SISWA SMP TERHADAP KEMAMPUAN PENALARAN MATEMATIS. Journal on Education, 1(2), 288-296.

Harris, J., H., and L., G., Katz, 2001. Young investigators: The project approach in the early years. New York: Teachers College Press.

Hmelo-Silver, C. E. (2004). Problem-based learning: What and how do students learn?. Educational psychology review, 16(3), 235-266.

Hung, W., Jonassen, D. H., \& Liu, R. (2008). Problem-based learning. Handbook of research on educational communications and technology, 3(1), 485-506.

Jabar, A. (2013). Pembelajaran Elektronik pada Matematika. Lentera Jurnal Pendidikan, 8(1)

Jung,H., Jun.,W., and L. Gruenwald. 2001. A Design and Implementation of Web-Based Project-Based Learning Support Systems. (www.cs.ou.edu/ database/documents/jjg01.pdf) pada 20 April 2021.

Kongchan, C.(2012). How a Non-Digital Native Teacher Makes Use of Edmodo. International Confrence ICT for Language Learning: Florence, Italy.

Martinez, F., Herrero, L., C., and S., Pablo, 2010. Project-Based Learning and Rubrics in the Teaching of Power Supplies and Photovoltaic Electricity. IEEE TRANSACTIONS ON EDUCATION. 54(1), (March), PP. 87-96.

Meyer, B., Haywood, N., Sachdev, D., \& Faraday, S. (2008). What is independent learning and what are the benefits for students. Department for Children, Schools and Families Research Report, 51.

Mokhtar, and Alia, Farha.(2018). Breaking Barriers through Edmodo: A Qualitative Approach on the Perceptions of University of Malaya Undergraduates. Online Learning Journal. 22 (1). 
Moursund, D. 1999. Project Based Learning Using Information Technology, ISTE. Publications.

Musfiqon. (2012). Development of learning media and sources. Jakarta: Prestasi Pustakaraya.

Nafiah, Y. N., \& Suyanto, W. (2014). Penerapan model problem-based learning untuk meningkatkan keterampilan berpikir kritis dan hasil belajar . Jurnal Pendidikan Vokasi, 4(1).

Nee, C.K. (2014). The Effect of Educational Networking on Students' Performance Biology. International Journal on Integrating Tecnologv in Education, 3(1), 21-41.

Rulviana, V. (2018). Implementasi Media Edmodo Dalam Mata Kuliah Pengembangan Kurikulum Sekolah Dasar. Refleksi Edukatika: Jurnal IImiah Kependidikan, 8(2).

Rustyani, N., Komalasari, Y., \& Bernard, M. (2018). UPAYA MENINGKATKAN DISPOSISI DENGAN PENDEKATAN OPEN ENDED PADA SISWA SMK KELAS X-RPL B. Journal on Education, 1(2), 265270.

Sanaky, H. A. (2009). Learning media. Yogyakarta: Safiria Insania Pres

Smith, Elizabeth Hanson and Sarah Riling. 2006. Learning Language Through Technology. TESOL,Inc. Virginia. USA.

Suhendri, H. (2011). Pengaruh kecerdasan matematis-logis dan kemandirian belajar terhadap hasil belajar matematika. Formatif: Jurnal Ilmiah Pendidikan MIPA, 1(1).

Yancey, Kathleen Black. 2009. Writing by Any Other Name. Principal Leadership. 